\title{
Evaluation of full length E1 and E2 glycoproteins of HCV expressed in $P$. pastoris as a protein-based vaccine candidate
}

\author{
Rahimi $\mathbf{P}^{1^{*}}$, Solati $\mathbf{R}^{2}$, Shokri $\mathbf{M}^{3}$, Vahabpour $\mathbf{R}^{1}$, Mahmoudizad $\mathbf{F}^{4}$, Aghasadeghi MR $\mathbf{R}^{1}$, Motevalli $\mathbf{F}^{1}$, Yazdani $\mathbf{S h}^{5}$, \\ Shayestehpour $\mathbf{M}^{5}$, Amiran $\mathbf{M R}^{1}$ \\ ${ }^{1}$ Department of Hepatitis and AIDS, Pasteur Institute of Iran. \\ ${ }^{2}$ MSc student in Microbial Biotechnology, Payameh Nour University, Tehran, Iran. \\ ${ }^{3} \mathrm{Ph} . \mathrm{D}$ student , Department of Immunology, Pasteur Institute of Iran. \\ ${ }^{4}$ MSc student, Department of Microbiology, Islamic Azad University, Pharmaceutical Science Branch, Tehran, Iran. \\ ${ }^{5} \mathrm{Ph} . \mathrm{D}$ student, School of Public Health, Tehran University of Medical Sciences, Tehran, Iran.
}

\begin{abstract}
Introduction: The development of an effective vaccine against Hepatitis $\mathrm{C}$ virus (HCV) is still a target of intensive vaccine research. The HCV envelope proteins E1 and E2 which can induce broadly neutralizing antibodies are the major candidate for this purpose. Different types of expression systems have been used to express these glycoproteins. In this study, an expression system using Pichia pastoris was used to express E1 and E2 in full length. Methods: E1 and E2 regions containing the restriction sites from HCV $1 \mathrm{~b}$ were separately amplified and cloned into a pPICZAa vector. The $\mathrm{km} 71 \mathrm{~h}$ strain of $P$. pastoris was transfected with the confirmed vectors separately using electroporation. The recombinant E1 and E2 proteins were evaluated for their antigenicity in an ELISA test and the induction of humoral immunity in mice. Results: The expression of full length HCV glycoproteins E1 and E2 in P. pastoris strain $\mathrm{km} 71 \mathrm{~h}$ was successfully achieved and their specific antibody was detected in serum samples from HCV infected patients. Furthermore, the recombinant glycoproteins could elicit a significant humoral immunity in mice as a vaccine candidate. Conclusion: P. pastoris is one of the best eukaryotic expression systems for the production of HCV glycoproteins in full length and the expressed proteins could be used in diagnostic tests such as ELISA. The induction of humoral immune responses in mice should lead to further studies on these glycoproteins for designing an effective vaccine.
\end{abstract}

KEYWORDS: HCV E1 and E2, Pichia pastoris, Yeast expression system, Protein-based vaccine.

\section{INTRODUCTION}

Hepatitis $\mathrm{C}$ virus $(\mathrm{HCV})$ is an enveloped virus in Flaviviridae family with a positive-stranded RNA genome of approximately $9.5 \mathrm{kbp}$ which encodes a single 3010 to 3033 amino acid polyprotein. This poly-protein is processed by cellular and viral proteases to produce the mature structural and nonstructural proteins, namely C, E1, E2, p7, NS2, NS3, NS4A, NS4B, NS5A and NS5B [1,2 ]. Among them, E1 and E2 are two structural proteins with several glycosylation sites which are enveloped membrane anchor glycoproteins with an ability to interact non-covalently with each other to form heterodimers [2-5]. The hydrophobic carboxyl-terminal (C-terminal) region of these proteins act as membrane anchors. Therefore, the

\footnotetext{
*Corresponding Author: Pooneh Rahimi, Ph.D Associate Professor, Department of Hepatitis and AIDS, Pasteur Institute of Iran, Tehran, Iran Email: pooneh5376@yahoo.com, prahimi@pasteur.ac.ir Tel/Fax: (+98) 2166969291
}

deletion of this region is necessary for their secretion, especially when they are expressed in Escherichia coli [2-7].

The eukaryotic systems are known as the best expression systems, especially when a high yield production and posttranslational modifications such as glycosylation, methylation and acylation are needed. Amongst them, the yeast systems have several advantages over other expression systems [8,9]. Pichia pastoris is considered as one of the better eukaryotic expression systems due to its ability for protein processing and folding, posttranslational modifications and its ease of manipulation, similar to E. coli or Saccharomyces cerevisiae [811]. Since it has been proposed that an antibody response against the envelope proteins is important for neutralization and clearance of the virus $[15,17]$, we tried to express these viral glycoproteins in a host which is able to perform posttranscriptional modifications on the recombinant proteins with a high yield production.

There are many studies on expression of viral proteins 
including different $\mathrm{HCV}$ proteins in yeast expression system such as $S$. cerevisiae and P. Pastoris [ 8, 10-17 ]. Herein, the HCV E1 and E2 glycoproteins from HCV genotype 1b were expressed in full length in $P$. pastoris for the first time. Moreover, we investigated the antigenicity of these proteins by detecting its specific antibody in $\mathrm{HCV}$-infected patients and the induction of humoral response in the immunized mice.

\section{MATERIALS and METHODS}

\section{PCR and cloning}

HCV E1 and E2 (from base pairs 1490-2608 in genotype 1b (NCBI accession numbers KU879443 and DQ682381, respectively) were commercially synthesized by Biomatik (Canada) and were used as a PCR template along with primers designed by CLC workbench and Gene Runner software, containing EcoR1 and Nde1 for E1 primer pairs as well as $E c o R I$ and $X b a \mathrm{I}$ restriction sites for E2 primer pairs, as shown below:

\section{E1+NdeI Forward: 5' - CATATGGCTGCCCAGGTGAAGA} -3' and E1+EcoRI reverse: 5' GAATTCTTAGGTGCCCGCGTCCA -3'.

E2+EcoRI Forward: 5'- GAA TTC GGC ACC ACCACC GT-3' and E2+XbaI reverse: 5'- TCT AGA GAC CAA CTT CTC CAA TGC-3'.

To amplify the full length E1 and E2 separately, PCR was carried out in a $50 \mu 1$ reaction mixture consisting of $10 \mathrm{x}$ pfu amplification buffer $(5 \mu \mathrm{L}$; Thermo Scientific, Fermentas, Lithuania), $1 \mu \mathrm{L}$ of $10 \mathrm{mM}$ dNTPs (Thermo Scientific, Fermentas, Lithuania), $2 \mu \mathrm{L}$ of each forward and reverse primers $(10 \mathrm{pmol} / \mu \mathrm{L}), 2 \mu \mathrm{L}$ of each template DNA $(13 \mathrm{ng} / \mu \mathrm{L}), 1 \mu \mathrm{L}$ of $2.5 \mathrm{u} / \mu \mathrm{L}$ Pfu DNA polymerase (Thermo Scientific, Fermentas, Lithuania) and $37 \mu \mathrm{L}$ double-distilled water. The thermo cycling program at first denaturation was $5 \mathrm{~min}$ at $94^{\circ} \mathrm{C}$, then $94^{\circ} \mathrm{C}$ for $45 \mathrm{~s}$, followed by 35 cycles of $95^{\circ} \mathrm{C}$ for $5 \mathrm{~s}, 60^{\circ} \mathrm{C}$ for $45 \mathrm{~s}, 72^{\circ} \mathrm{C}$ for 90 s with a final extension at $72^{\circ} \mathrm{C}$ for $5 \mathrm{~min}$.

Another $25 \mu \mathrm{L}$ PCR was performed to prepare each previously mentioned PCR product for TA-cloning with the same reagents. The reaction mixture contained $12 \mu \mathrm{L}$ of each first PCR product, $1 \mu \mathrm{L}$ of Taq DNA polymerase, $0.5 \mu \mathrm{L}$ of dNTP, $2.5 \mu \mathrm{L}$ of $10 \mathrm{x}$ Taq amplification and $9 \mu \mathrm{L}$ double-distilled water. The thermo cycling profile was the same as the first PCR. Both PCR products underwent electrophoresis on a $1.5 \%$ agarose gel containing $0.5 \mu \mathrm{g} / \mathrm{ml}$ ethidium bromide (CinaClone, Iran). The amplified products were ligated into a T-PTG19 vector using $10 \mu \mathrm{L}$ of the insert DNA $(92 \mathrm{ng} / 5 \mu \mathrm{l})$ and $10 \mu \mathrm{L}$ of the T-vector DNA (PCR Cloning Vector PTG 19, 25ng/ $\mu 1$, Vivantechnologies) and $1 \mu \mathrm{L}$ of T4 DNA ligase (LithuaniaThermo Scientific- Fermentas,) and $2 \mu \mathrm{L}$ T4 ligase buffer (Lithuania - Thermo Scientific- Fermentas, 10X). The reaction mixture was incubated at $4{ }^{\circ} \mathrm{C}$ for $16 \mathrm{~h}$. Five $\mu \mathrm{L}$ of this ligation reaction was used to transform E. coli DH5a competent cells using the heat shock and $\mathrm{CaCl} 2$ method. The transformed cells were grown on low salt LB agar plates containing $(50 \mu \mathrm{g} / \mathrm{ml}$ ampicillin) and the plates were incubated at $37^{\circ} \mathrm{C}$ for overnight. T-vector DNA construct was isolated using QIAprep spin Miniprep Kit (Qiagen, Germany) and verified by PCR using (Master Mix Red- Taq 2x,1.5mM MgCl2, Ampliqon, Denmark) as well as restriction enzyme digestion. For E1 gene, $26 \mu \mathrm{L}$ of $65 \mathrm{ng} / 5 \mu \mathrm{l}$ isolated DNA, $2 \mu \mathrm{L}$ of each NdeI and EcoRI restriction enzymes, $4 \mu \mathrm{L}$ of $10 \mathrm{X}$ orange buffer were incubated for $24 \mathrm{~h}$ at $37^{\circ} \mathrm{C}$. For E2 gene, in a $25 \mu \mathrm{L}$ reaction mixture, $20 \mu \mathrm{L}$ of $60 \mathrm{ng} / 5 \mu \mathrm{l}$ of isolated DNA, $2.5 \mu \mathrm{L}$ of $\mathrm{Xba \textrm {I }}$ restriction enzyme and $2.5 \mu \mathrm{L}$ of Tango buffer (Thermo Scientific, Fermentas, Lithuania) were incubated for $16 \mathrm{~h}$ at $37^{\circ} \mathrm{C}$. For E2 gene second restriction enzyme reaction, $1 \mu \mathrm{L}$ of $E c o R \mathrm{I}$ and $2 \mu \mathrm{L}$ of each $10 \mathrm{X}$ Fast buffer and green buffer (Thermo Scientific- Fermentas, Lithuania ) were mixed and incubated at $37^{\circ} \mathrm{C}$ for $1 \mathrm{~h}$. Samples were analyzed on $1 \%$ agaros gel. The bands of E1 and E2 genes were purified using the QIAquick Gel Extraction Kit (Qiagen, Hilden, Germany).

E. coli strain DH5a containing pPICZAa vector was grown on LB broth containing $25 \mu \mathrm{g} / \mathrm{ml}$ zeocinTM (Invitrogen, USA) antibiotic in $37^{\circ} \mathrm{C}$ for $16 \mathrm{~h}$ in shaking incubator (300rpm). pPICZAa vectors were isolated by using QIAprep spin MAXI prep Kit (Qiagen, Hilden, Germany) and verified by enzyme digestion reaction containing $1 \mu \mathrm{l}$ of each $N d e \mathrm{I} / E c o R \mathrm{I}$ and $E c o R \mathrm{I} / \mathrm{Xba \textrm {I }}$ for $30 \mathrm{~min}$ at $37^{\circ} \mathrm{C}$. The ligation reaction in upstream of the $6 \times$ histidine tag was performed in a reaction mixture containing $10 \mu \mathrm{L}$ of digested PCR product of E1 and E2 genes separately as described previously (with concentration of $65 \mathrm{ng} / 5 \mu \mathrm{l}$ and $60 \mathrm{ng} / 5 \mu \mathrm{Lf}$ or E1 and E2 genes ,respectively ), $5 \mu \mathrm{L}$ of pPICZAa vector with concentration of $90 \mathrm{ng} / 5 \mu 1,1 \mu \mathrm{L}$ of T4 DNA ligase (Thermo Scientific, Fermentas, Lithuania ,1 weiss $\mathrm{u} / \mathrm{ml}, 200 \mathrm{u}$ ) and $2 \mu \mathrm{L}$ of $10 \mathrm{X}$ ligase buffer (Thermo Scientific, Fermentas, Lithuania ).The two mixtures were incubated in $4^{\circ} \mathrm{C}$ for $16 \mathrm{~h}$. Ten $\mu \mathrm{L}$ of each ligation reaction was used to transform E. coli DH5a competent cells by the heat shock method. The selection was done by plating the cells on LB agar containing $(25 \mu \mathrm{g} / \mathrm{ml}$ Zeocin: $100 \mathrm{mg} / \mathrm{ml})$, incubation at $37^{\circ} \mathrm{C}$ for $16-18 \mathrm{~h}$ overnight and at dark. pPICZAa vectors were isolated from several colonies using QIAprep spin Miniprep Kit and were verified by enzyme digestion reaction (NdeI/EcoRI

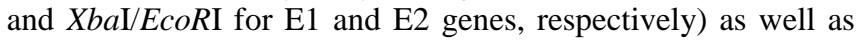
PCR and sequencing using Master Mix Red- Taq 2x, $1.5 \mathrm{mM}$ $\mathrm{MgCl}$ 2(Ampliqon, Denmark) AOX1 universal primers (BioNeer, South Korea). pPICZAa-E1 and pPICZAa-E2 constructs were linearized using the restriction enzyme SacI (5000u, $40 \mathrm{u} / \mu \mathrm{L}$, Roche, Germany) for $16 \mathrm{~h}$ at $37^{\circ} \mathrm{C}$ and were isolated by a gel extraction kit (YTA Plasmid DNA Extraction Mini Kit, Iran). The density of the gel-extracted products for E1 and E2 were $37.1 \mu \mathrm{g}$ and $35.2 \mu \mathrm{g}$, respectively.

\section{Transformation of competent $\boldsymbol{P}$. pastoris strains}

Control flow test: $P$. pastoris strain km71h strain was selected on minimal dextrose (MD) medium plate and confirmed on minimal methanol (MDH) medium plate and yeast extract peptone dextrose (YPD) medium plate containing $100 \mu \mathrm{g} / \mathrm{ml}$ zeocin antibiotic. Moreover, the strain was grown separately on media plates without the antibiotic. All plates were incubated for $72 \mathrm{~h}$ at $28-30^{\circ} \mathrm{C}$ in dark. The confirmation of $\mathrm{km} 71 \mathrm{~h}$ strain was done through not growing in a medium containing zeocin and growing in a non-zeocin medium. Then the strain was regrown in YPD broth and was incubated at $28-30^{\circ} \mathrm{C}$ in a shaking incubator (300rpm) to reach OD $1.3-1.5$ at $600 \mathrm{~nm}$. Then $40 \mathrm{ml}$ of $5 \mathrm{X}$ sorbitol $(36.4 \mathrm{~g}$ of sorbitol was dissolved in $20 \mathrm{ml}$ doubledistilled water and filtered) was added to the medium and incubated in $20-30^{\circ} \mathrm{C}$ in shaking incubator with the speed range of 100-110rpm to prepare the competent $\mathrm{km} 71 \mathrm{~h}$ cells. pPICZAa- E1 and pPICZAa-E2, were linearized and km71h were transformed by electroporation method using Mini GenePulser apparatus (Bio Rad, USA, Gen Pulser X Cell; 2000w, $25 \mu \mathrm{f}, 200 \Omega, 5 \mathrm{~ms})$. The transformed cells were selected on YPD, yeast extract peptone dextrose medium plate with different concentrations of 50,100, 1000 and $1500 \mu \mathrm{g} / \mathrm{ml}$ zeocin for $72 \mathrm{~h}$ at $28-30^{\circ} \mathrm{C}$ in darkness. Both transformed strains were 
grown at $28-30^{\circ} \mathrm{C}$ for 2 days in $20 \mathrm{ml}$ of YPD broth containing $100 \mu \mathrm{g} / \mathrm{ml}$ zeocin.

\section{Genomic DNA Extraction of $\boldsymbol{P}$. pastoris}

Genomic DNA of the transformed cells were extracted using a mixture containing acid-washed glass beads with the size of 300 and 700 micron $(0.2 \mathrm{~g}$ of each size; SIGMA Glass Beads 710-1, 180 microns ,USA) with $200 \mu \mathrm{L}$ of phenol-chloroform prepared on ice and $100 \mu \mathrm{L}$ of isoamyl - alcohol incubated at $4^{\circ} \mathrm{C}$ in darkness. The micro tubes were centrifuged in 2000rpm for $5 \mathrm{~min}$. Then the supernatants were discarded and $250 \mu \mathrm{L}$ of TEN buffer (at first $0.12 \mathrm{~g}$ of Tris- $\mathrm{HCl} 10 \mathrm{mM}, 0.04 \mathrm{~g}$ of EDTA $1 \mathrm{mM}, 0.58 \mathrm{~g}$ of $\mathrm{NaCl} 0.1 \mathrm{M}, 2 \mathrm{ml}$ of $2 \%$ Triton $\mathrm{X}-100$ and $1 \mathrm{~g}$ of $1 \%$ Sodium Lauryl Sulfate were dissolved in $50 \mathrm{ml}$ water to a final volume of $100 \mathrm{ml}$ with $\mathrm{pH} 8$ ) were added to the pellet to resolve it. The mixture was then processed according to the phenol-chloroform DNA extraction protocol. Finally, to verify the recombinant yeast DNA, colony PCR was performed using Master Mix Red- Taq 2x, forward and reverse specific primers for E1 and E2 genes separately. Another colony PCR was also done using the AOX1 and AOX2 primers. PCR amplicons were analyzed by electrophoresis on $1 \%$ agarose gel. Nucleotide sequencing was also done for further confirmation.

E1 and E2 Expression, purification and verification of recombinant protein

One colony of each E1 and E2 gene transformed into the yeast was grown in $5 \mathrm{ml}$ YPD broth without antibiotic in $28-30^{\circ} \mathrm{C}$ for 1 day. Then it was centrifuged in $2000 \mathrm{rpm}$ for $5 \mathrm{~min}$ and the pellet was re-suspended by adding $20 \mathrm{ml}$ of buffer complex medium containing glycerol (BMGY). Cells were re-grown in $28-30^{\circ} \mathrm{C}$ to reach to the optical density of $2-10$ in $600 \mathrm{~nm}$. Two $\mathrm{ml}$ of un-induced sample was collected and the remaining $18 \mathrm{ml}$ was centrifuged. The pellet was resolved in $20 \mathrm{ml}$ yeast nitrogen base amino acids medium (YNB) containing $1 \%$ methanol. Cells were grown in $28-30^{\circ} \mathrm{C}$ in shaking incubator for 5 days. Samples were collected every $24 \mathrm{~h}$. Finally, Trichloroacetic acid (TCA) $100 \%$ was used to purify the secreted proteins. The Cterminal $6 \times$ His-tagged of each E1 and E2 recombinant protein was bound to Ni-NTA agarose beads and proteins were purified under native conditions with imidazole separately, according to the manufacturer's instructions (QIAGEN, Life Technologies, Germany) and subsequently, the eluted fractions were subjected to $12 \%$ polyacrylamide (v/v) SDS-PAGE gel electrophoresis. The purity and quantity of each protein was verified with Coomassie blue staining as compared to a known protein. Western blotting was carried out for each protein separately through electro-transfer of proteins from polyacrylamide gel to nitrocellulose membrane (Millipore, USA) at $20 \mathrm{~V}$ for $1 \mathrm{~h}$. The membrane was treated with a PBS blocking buffer containing $2 \%$ non-fat dried milk (SigmaAldrich, USA) for $2 \mathrm{~h}$ with shaking. After removing the blocking buffer, the membrane was incubated with Anti-His(Cterm) antibody (diluted: 1/2000; Abcam Ms Mab and the secondary antibody (M-IgG-HRP diluted 1/10000; Abcam, Ms Mab) for $1 \mathrm{~h}$. After three rounds of washing, the bands corresponding to the appropriate proteins became visualized by adding 3,3',5,5'-tetramethylbenzidine (TMB) chromogenic substrate (Roche Diagnostics GmbH, Germany). Then E1 and E2 were eluted with $20 \mathrm{~m}$ MTris- $\mathrm{HCl}(\mathrm{pH} 9.3)$ and further purified with Sephadex G150 column for removing low molecular weight fractions. Then they were dialyzed against $5 \mathrm{mM}$ Tris- $\mathrm{HCl}$ ( $\mathrm{pH} 9.3$ ) and sterilized with $0.45 \mu \mathrm{m}$ filter, and then stored at $4^{\circ} \mathrm{C}$.

Concentration of the dialyzed proteins was measured by using the Bradford method [16].

Evaluation of recombinant E1 and $\mathrm{rE2}$ specific antibody in human serum using ELISA

Plasma samples from $60 \mathrm{HCV}$ chronic infected patients and from 20 healthy volunteers were used to evaluate the $\mathrm{rE} 1$ and rE2 specific antibodies. $100 \mu \mathrm{l}$ of $1 \mu \mathrm{g} \mathrm{ml}-1$ of each purified E1 and E2 in carbonate coating buffer $(0.15 \mathrm{M}$ sodium carbonate, $0.435 \mathrm{M}$ sodium bicarbonate, $0.03 \mathrm{M}$ sodium azide, $\mathrm{pH}$ 9.6) was coated on the 96-well microplates separately. Microplates were stored at $4{ }^{\circ} \mathrm{C}$ overnight. Washing solution containing PBS/0.5\% Tween 20 was used to wash the plates for 6 times. Then, the plates were blocked with $100 \mathrm{ml}$ PBS/ $0.05 \%$ Tween $20 / 4 \%$ BSA per well at $37^{\circ} \mathrm{C}$ for $2 \mathrm{~h}$. The plates were then washed six times with washing solution. Each plasma samples was serially diluted twofold in PBS/0.05\% Tween 20/2\% BSA starting from $1: 100$ to $1: 400$. Hundred $\mu \mathrm{l}$ of each dilution was added in duplicate to each well of microplates and incubated at $37^{\circ} \mathrm{C}$ for $1 \mathrm{~h}$. Microplates were washed using the washing solution. Then, 100ml 1:2000-diluted horseradish peroxidase-conjugated (HRP) anti-human IgG isotyping monoclonal antibody (Sigma) was added per well and incubated at $37^{\circ} \mathrm{C}$ for $1 \mathrm{~h}$. Plates were washed with washing solution then, $100 \mathrm{ml}$ TMB substrate was added per well. Plates were incubated at room temperature in darkness for $10 \mathrm{~min}$. Hundred $\mu \mathrm{l}$ of $2 \mathrm{M}$ sulfuric acid was added to each well to stop the reaction. The absorbance of each well was read at $450 \mathrm{~nm}$. The mean absorbance value of those 20 healthy volunteers plus $2 \mathrm{SD}$ was used to determine the cut-off. A serum sample was considered positive when the absorbance was equal or above the cut-off.

\section{Mice immunization}

The female BALB/c mice aged 6-8 weeks were divided into 3 groups of six for each E1 and E2 separately. Each group was immunized 3 times subcutaneously at multiple sites in tail base at weeks 0, 3 and 6 with $20 \mu \mathrm{g}$ of each purified E1 or E2 alone diluted in sterilized PBS, E1 or E2 separately in combination with Freund's adjuvant (Sigma, USA) in $50 \mu 1$ of PBS, for the first immunization and incomplete adjuvant in $100 \mu \mathrm{L}$ of PBS was used as booster, (Sigma, USA).In each group of E1 and E2, 6 mice were injected with PBS and Freund's adjuvant alone as negative control. Mouse blood samples were collected from retro-orbital bleeding at weeks 0,5 , and 8 and the sera were stored at $-70^{\circ} \mathrm{C}$ for further processing.

Evaluation of anti-E1 and anti-E2 antibodies in immunized mice

Indirect ELISA was used to evaluate the anti-E1 and anti-E2 antibodies in immunized mice. Briefly, $5 \mu \mathrm{g}$ of each purified E1 and E2 protein was coated in ELISA plates overnight at $4^{\circ} \mathrm{C}$. For evaluation of the total $\mathrm{IgG}$ and $\mathrm{IgG}$ isotyping serum dilution of 1:500 and 1:1000 of each mouse were prepared respectively. The diluted serums were added in triplicate to each well and incubated for $1 \mathrm{~h}$ at $37^{\circ} \mathrm{C}$, washed and further incubated with HRP-conjugated goat anti-mouse IgG (dilution1:10000) as secondary antibody. After adding the TMB, color development was measured at $450 \mathrm{~nm}$. IgG isotyping was done as described above using goat anti-mouse IgG1, IgG2a, and IgG2b antibodies in dilution of 1:2000 at room temperature (Sigma, USA) and HRP-labeled anti-goat IgG conjugate (dilution 1:10000 at room temperature).

\section{Statistical analysis}

Distribution of data was normalized by logarithmic transformation using GraphPad Prism 6. Statistical analyses for differences in antibody titer against HCV E1 and E2 protein between groups were then carried out using one-way ANOVA 
and Bonferroni's multiple comparisons tests. The results were considered statistically significant when $\mathrm{P}$-values were equal to or less than 0.05 .

\section{RESULTS}

The E1 and E2 regions were amplified separately by PCR using their specific primers. The PCR products were analyzed under gel electrophoresis and the bands with sizes of 576bp for E1 and 1100-bp for E2 were observed along with a band of 4176bp for an undigested pPICZAa-E1 and a 4500-bp band for an undigested pPICZAa-E2 as well as a 3600-bp band for a semidigested pPICZAa fragment using XbaI restriction enzyme. The pPICZAa-E1 and pPICZAa-E2 constructs were verified by restriction digestion reactions using NdeI/EcoRI and EcoRI/XbaI pairs, respectively. The results are depicted in Fig.1.

The recombinant E1 and E2 proteins were purified using NiNTA agarose and were verified using SDS-PAGE and Western blotting analyses. The recombinant proteins were then dialyzed overnight through a membrane with a cut-off of below $50 \mathrm{kDa}$, against PBS $0.9 \%$ in room temperature and their concentrations were assayed by Bradford method which was estimated to be 6 $\mathrm{mg} / \mathrm{L}$ and $4 \mathrm{mg} / \mathrm{L}$ for E1 and E2, respectively.

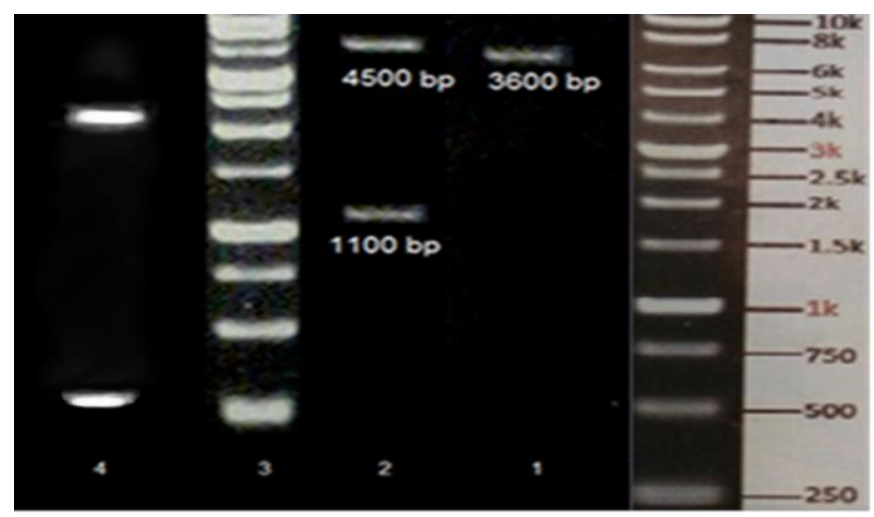

Fig. 1. Digestion reactions of pPICZAa-E1 and pPICZAa-E2 using $N d e \mathrm{I} / E c o R \mathrm{I}$ and $E c o R \mathrm{I} / \mathrm{Xba \textrm {I }}$ restriction enzymes, respectively.

Lane 1: a semi-digested non-recombinant pPICZAa (3600bp), Lane 2: upper band (4500bp); undigested pPICZAa-E2, lower band (1100bp); digested pPICZAa-E2 by using the EcoRI and XbaI. Lane 3: DNA ladder (1kb). Lane 4: upper band (4176bp); undigested pPICZAa-E1, lower band (576bp): digested pPICZAa- E1 by using NdeI/EcoRI restriction enzymes. $P$. pastoris strain $\mathrm{km} 71 \mathrm{~h}$ was transfected by the linearized pPICZAa-E1 and pPICZAa-E2 separately. Different concentrations of zeocin were used to evaluate the resistance of the colonies of $\mathrm{km} 71 \mathrm{~h}$ strain and those resistant colonies in concentration of $100 \mu \mathrm{g} / \mathrm{ml}$ of zeocin selected for the expression.

\section{Detection of E1 and E2 specific antibody in patients with chronic HCV infection}

The evaluations of specific anti-E1 and anti-E2 antibodies were done using an in-house ELISA test. The mean absorbance values of 20 healthy volunteers using $2 \mathrm{SD}$ calculations were used to determine the cut-off. A serum sample was considered positive when the absorbance was equal or above the cut-off which was calculated by the following formula:

Cut-off $=$ Mean $+2 \mathrm{sd}+0.05$

$=0.1+0.14+0.05$

Cut-off $=0.29$
The identification of recombinant HCV E1 and E2 expression in cell lysates of $P$. pastoris $\mathrm{km} 71 \mathrm{~h}$ strain using HRPconjugated anti-His polyclonal antibody. On the blotted membrane, 2 bands for E1 (Lane 1) and E2 (Lane 3) with molecular weights of approximately $25 \mathrm{kDa}$ and $85 \mathrm{kDa}$ were detected, respectively. Lane 2: Pre-stained protein molecular weight marker (20-120kDa).

Detection of E1 and E2 specific antibody in patients with chronic HCV infection

The evaluations of specific anti-E1 and anti-E2 antibodies were done using an in-house ELISA test. The mean absorbance values of 20 healthy volunteers using 2 SD calculations were used to determine the cut-off. A serum sample was considered positive when the absorbance was equal or above the cut-off which was calculated by the following formula:

Cut-off $=$ Mean $+2 \mathrm{sd}+0.05$

$=0.1+0.14+0.05$

Cut-off $=0.29$

There was a significant difference in anti-E1 and anti-E2 antibodies titers in the serum samples with dilution of 1:400 between the healthy volunteers and HCV chronic infected patients .The high antibody titer against both E1 and E2 was detected in patients with HCV chronic infection with the above cut-off value.

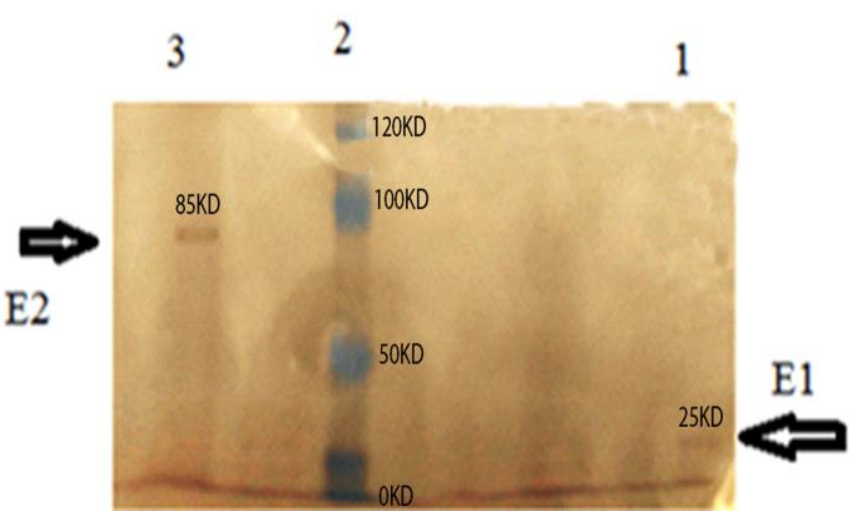

Fig. 2. Western blotting of recombinant HCV E1 and E2 glycoproteins expressed in P. pastoris.

The identification of recombinant HCV E1 and E2 expression in cell lysates of $P$. pastoris $\mathrm{km} 71 \mathrm{~h}$ strain using HRP-conjugated anti-His polyclonal antibody. On the blotted membrane, 2 bands for E1 (Lane 1) and E2 (Lane 3) with molecular weights of approximately $25 \mathrm{kDa}$ and $85 \mathrm{kDa}$ were detected, respectively. Lane 2: Pre-stained protein molecular weight marker (20-120kDa).

There was a significant difference in anti-E1 and anti-E2 antibodies titers in the serum samples with dilution of 1:400 between the healthy volunteers and HCV chronic infected patients .The high antibody titer against both E1 and E2 was detected in patients with HCV chronic infection with the above cut-off value. 


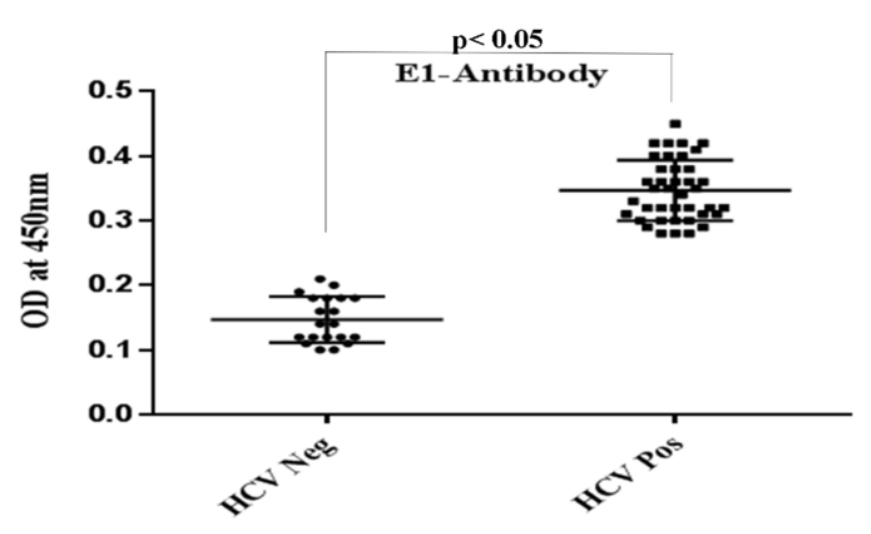

Fig. 3. ELISA assay for detection of anti -E1 specific antibody in 20 healthy volunteers and $60 \mathrm{HCV}$ chronic infected patients using purified recombinant $\mathrm{E} 1$ as the antigen.

\section{Evaluation of specific anti-E1 and anti-E2 total IgG and} its subclasses in immunized mice

The antibody response in mice that were immunized separately with either E1 plus complete Freund's adjuvant and E2 plus complete Freund's adjuvant were significantly higher in comparison with mice that were immunized with each of E1 or E2 recombinant proteins alone. Also, the antibody response

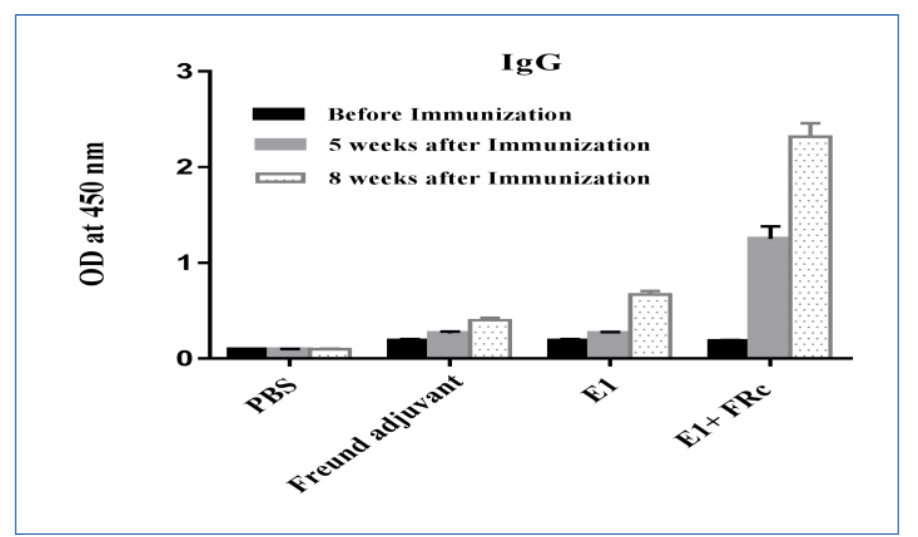

Fig. 5. ELISA analysis of humoral responses (Total $\operatorname{IgG}$ ) in mice immunized with PBS (negative control), complete Freund's adjuvant, E1 and E1 plus FRc.

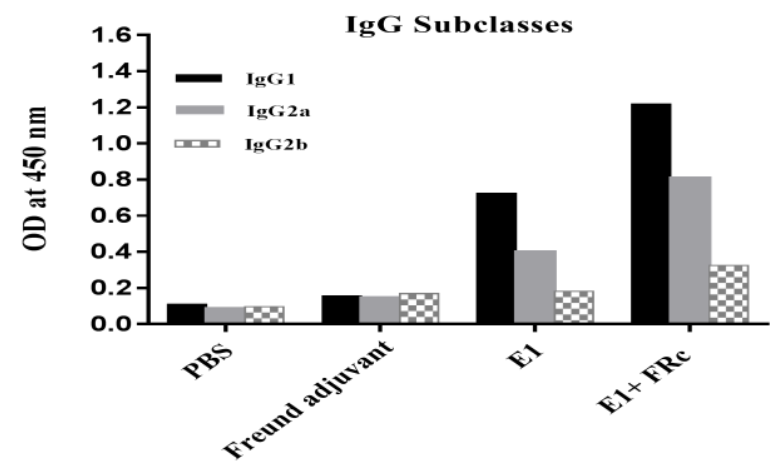

Fig. 7. Analysis of sub-classes of IgG antibody responses in mice pooled serum by ELISA test. Measurement of IgG sub-classes against E1 Ag.

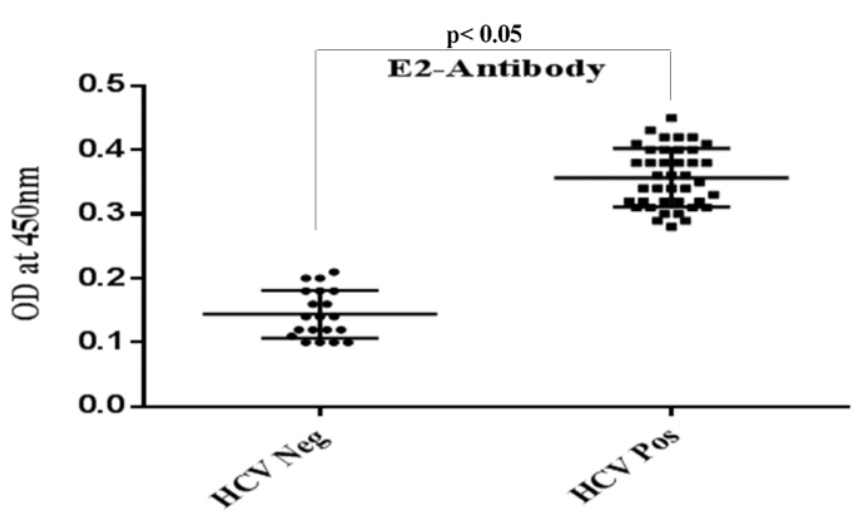

Fig. 4. ELISA assay for detection of anti-E2 in 20 healthy volunteers and $60 \mathrm{HCV}$ chronic infected patients using purified recombinant E2 as the antigen.

showed a significant raise in $\operatorname{IgG}$ titer after 8 weeks of immunization compared to the 5th week and before the immunization, respectively. $\mathrm{IgG} 1$ was the predominant isotype of detected IgG. Other identified IgG subclasses were IgG2a and $\operatorname{IgG} 2 \mathrm{~b}$. However, the difference between the titer of E1IgG1 and E2-IgG1 with the other subclasses of E1-IgG and E2IgG was not statistically significant.

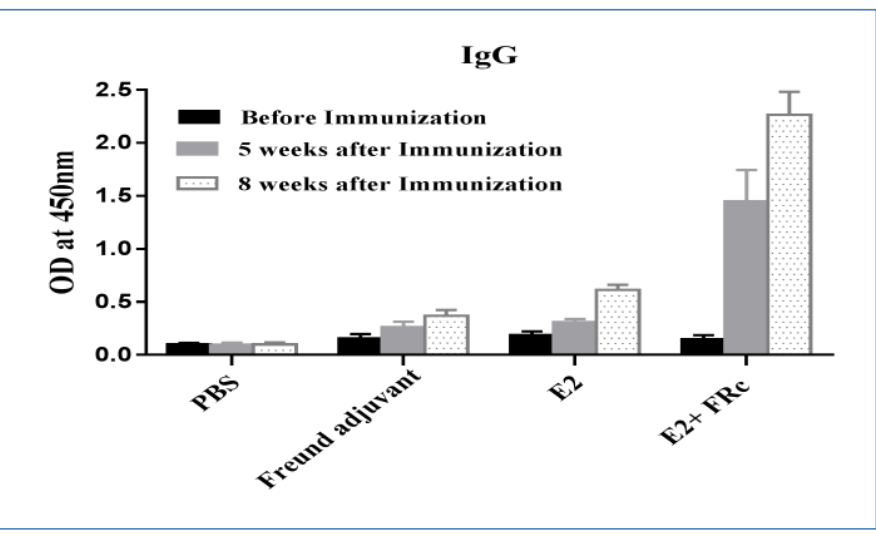

Fig. 6. ELISA analysis of humoral responses (total $\mathrm{IgG}$ ) in mice immunized with PBS (negative control), complete Freund's adjuvant, E2 antigen and E2 antigen plus complete Freund adjuvant (FRc). IgG total antibody titer was measured in mice pooled serum in separate ELISA tests.

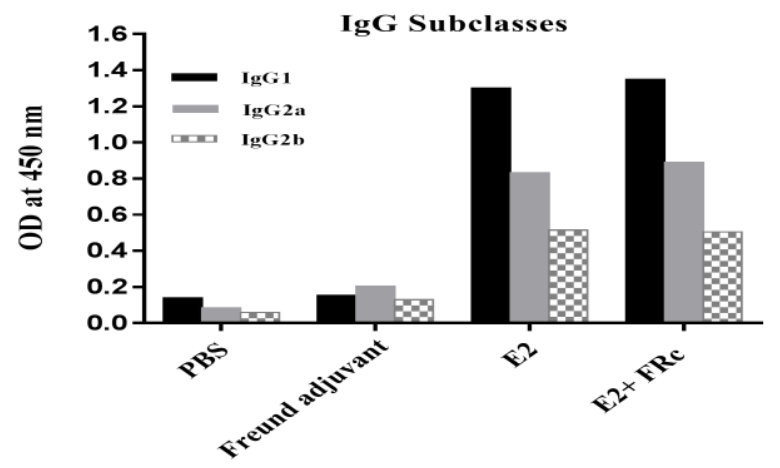

Fig. 8. Analysis of sub-classes of $\operatorname{IgG}$ antibody responses in mice pooled serum by ELISA test. Measurement of IgG sub-classes against E2 Ag. 


\section{DISCUSSION}

HCV infections with approximately 200 million chronic cases worldwide remain a serious global health burden. Only $30 \%$ of the infected patients can spontaneously resolve the infection and in some patients the infection may evolve into chronic hepatitis, cirrhosis, liver failure or hepatocellular carcinoma [14]. Previous studies have shown that CD8+ T cells are the key component for resolving HCV infection. However, neutralizing antibodies are also considered to be important in protecting people against the infection [1, 2]. Despite improved new therapeutic options, an effective and preventative vaccine against $\mathrm{HCV}$ is not yet available [2,3]. E1 and E2 are type I membrane glycoproteins and are generally believed to constitute the components of the virion membrane involved in the receptor binding and membrane fusion which promote $\mathrm{HCV}$ entry into the target cells and as a result, E1 and E2 are two major targets in HCV vaccine research. Several studies have demonstrated that E1 and E2 structural proteins induce the production of neutralizing antibodies; hence, they might be considered as future vaccine candidates [2-10].

Yeasts have the advantages of molecular and genetic manipulations and have the added advantage of 10 to 100 -fold higher heterologous protein expression levels. As a eukaryote, $P$. pastoris has many of the advantages of higher eukaryotic expression systems such as protein processing, protein folding and posttranslational modification. This system is faster, easier and less expensive to use than other eukaryotic expression protocols such as baculovirus or mammalian tissue culture while it generally gives higher expression levels. These features make Pichia a very useful protein expression system. $P$. pastoris is a methylotrophic yeast, capable of metabolizing methanol as its sole carbon source. Two genes in P. pastoris code for alcohol oxidase, namely AOX1 and AOX2. The AOX1 gene product accounts for the majority of alcohol oxidase activity in the cell. The AOX1 gene has been isolated and a plasmid-borne version of the AOX1 promoter is used to drive expression of the gene of interest encoding the desired heterologous protein. The expression of the AOX1 gene is tightly regulated and is induced by methanol to very high levels [12-15, 17-19]. Here, the pPICZ $\alpha$ A expression vector containing the $\alpha$-factor was used to express and secrete recombinant proteins in high volume. Therefore, we could produce both E1 and E2 glycoproteins with concentrations of 6 $\mathrm{mg} / \mathrm{L}$ and $4 \mathrm{mg} / \mathrm{L}$, respectively. The expression of these proteins is difficult because of their transmembrane domains which are highly hydrophobic [9, 14, 17-19]. Cai et al. expressed these viral glycoproteins known as rE1E2 in truncated form in P. pastoris with a yield of $35 \mathrm{mg} / \mathrm{L}$ [15]. However unlike rE1E2, we were able to express these 2 glycoproteins in their full lengths including their hydrophobic domains for the first time.

To evaluate the potential antigenicity of these proteins, they were used separately as the antigen in ELISA tests. The results showed that these yeast-expressed glycoproteins could be used in diagnostic methods to discriminate specific antibodies against $\mathrm{E} 1$ and $\mathrm{E} 2$ in $\mathrm{HCV}$ patients.

Our results were in agreement in terms of antigenicity with previous studies which had used a yeast expression system for producing E1 and E2 glycoproteins. However, they used it to express them in a truncated form as were the cases for rE1E2 or rCoreE1E2 [21-23]. Herein, we also investigated the immune reactivity of these 2 proteins in induction of neutralizing antibodies. Compared with the control groups of mice which were injected with complete Freund's adjuvant and each of E1 and E2 proteins alone, the injection with either E1 or E2 plus complete Freunds adjuvant could induce a higher titer of neutralizing antibody that were statistically significant. These results were consistent with previous studies which had evaluated these $\mathrm{HCV}$ glycoproteins in induction of humoral immune responses in animal models [21-23].

In this study, we could express two HCV glycoproteins in full length for the first time and the antigenicity of these recombinant proteins were evaluated by an ELISA test using the serum samples of $\mathrm{HCV}$ infected patients in comparison with healthy volunteers as well as the induction of neutralizing antibody in mice. In conclusion, our study exhibited the potential application of recombinant E1 and E2 HCV glycoproteins expressed in $P$. pastoris either as a vaccine candidate or as a diagnostic tool such as ELISA. However, further studies with incorporating adjuvants that could be used in humans are remained to be performed on this subject.

\section{ACKNOWLEDGEMENT}

We would like to appreciate all colleagues in Department of Hepatitis and AIDS of Pasteur Institute of Iran.

\section{CONFLICT OF INTEREST}

The authors declare that they have no conflict of interest.

\section{REFERENCES}

1. Matsuura Y, Miyamura T. The molecular biology of hepatitis $\mathrm{C}$ virus. Semin. Virol. 1993;4:297-304.

2. Charloteaux B, Lins L, Moereels H, Brasseur R. Analysis of the Cterminal membrane anchor domains of hepatitis $\mathrm{C}$ virus glycoproteins $\mathrm{E} 1$ and E2: toward a topological model. J Virol. 2002;76(4):1944-58.

3. Matsuura Y, Suzuki T, Suzuki R, Sato M, Aizaki H, Saito I et al. Processing of E1 and E2 glycoproteins of hepatitis C virus expressed in mammalian and insect cells. Virology. 1994;205(1):141-50. doi:10.1006/viro.1994.1629.

4. Dubuisson J, Hsu HH, Cheung RC, Greenberg HB, Russell DG, Rice $\mathrm{CM}$. Formation and intracellular localization of hepatitis $\mathrm{C}$ virus envelope glycoprotein complexes expressed by recombinant vaccinia and Sindbis viruses. J Virol. 1994;68(10):6147-60.

5. Dubuisson J, Rice CM. Hepatitis C virus glycoprotein folding: disulfide bond formation and association with calnexin. J Virol. 1996;70(2):778-86. 6. Michalak JP, Wychowski C, Choukhi A, Meunier JC, Ung S, Rice CM et al. Characterization of truncated forms of hepatitis $\mathrm{C}$ virus glycoproteins. J Gen Virol. 1997;78 ( Pt 9):2299-306. doi:10.1099/0022-1317-78-9-2299.

7. Liu J, Kong Y, Zhu L, Wang Y, Li G. High-level expression of the Cterminal hydrophobic region of HCV E2 protein ectodomain in E. coli. Virus Genes. 2002;25(1):5-13.

8. Buckholz RG, Gleeson MA. Yeast systems for the commercial production of heterologous proteins. Biotechnology (N Y). 1991;9(11):1067-72.

9. Demain AL, Vaishnav P. Production of recombinant proteins by microbes and higher organisms. Biotechnol Adv. 2009;27(3):297-306. doi:10.1016/j.biotechadv.2009.01.008.

10. Li P, Anumanthan A, Gao XG, Ilangovan K, Suzara VV, Duzgunes N et al. Expression of recombinant proteins in Pichia pastoris. Appl Biochem Biotechnol. 2007;142(2):105-24.

11. Ahmad M, Hirz M, Pichler H, Schwab H. Protein expression in Pichia pastoris: recent achievements and perspectives for heterologous protein production. Appl Microbiol Biotechnol. 2014;98(12):5301-17. doi:10.1007/s00253-014-5732-5.

12. Cregg JM, Vedvick TS, Raschke WC. Recent advances in the expression of foreign genes in Pichia pastoris. Biotechnology (N Y). 1993;11(8):905-10.

13. Ciarkowska A, Jakubowska A. Pichia pastoris as an expression system 
for recombinant protein production. Postepy biochemii. 2012;59(3):315-21. 14. Chen Y, Li Y, Liu P, Sun Q, Liu Z. Optimized expression in Pichia pastoris eliminates common protein contaminants from subsequent His-tag purification. Biotechnol Lett. 2014;36(4):711-8. doi:10.1007/s10529-0131411-3

15. Cai W, Su L, Liao Q, Ye L, Wu Y, Wu Z et al. Expression, purification and immunogenic characterization of hepatitis $C$ virus recombinant E1E2 protein expressed by Pichia pastoris yeast. Antiviral Res. 2010;88(1):80-5. doi:10.1016/j.antiviral.2010.07.007.

16. Bradford MM. A rapid and sensitive method for the quantitation of microgram quantities of protein utilizing the principle of protein-dye binding. Anal Biochem. 1976;72:248-54.

17. Lagging LM, Meyer K, Owens RJ, Ray R. Functional role of hepatitis C virus chimeric glycoproteins in the infectivity of pseudotyped virus. J Virol. 1998;72(5):3539-46.

18. Garcia JE, Puentes A, Suarez J, Lopez R, Vera R, Rodriguez LE et al. Hepatitis $\mathrm{C}$ virus (HCV) E1 and E2 protein regions that specifically bind to HepG2 cells. J Hepatol. 2002;36(2):254-62.

19. Triyatni M, Vergalla J, Davis AR, Hadlock KG, Foung SK, Liang TJ. Structural features of envelope proteins on hepatitis $\mathrm{C}$ virus-like particles as determined by anti-envelope monoclonal antibodies and CD81 binding. Virology. 2002;298(1):124-32.

20. Fazlalipour M, Keyvani H, Monavari SH, Mollaie HR. Expression, Purification and Immunogenic Description of a Hepatitis C Virus Recombinant CoreE1E2 Protein Expressed by Yeast Pichia pastoris. Jundishapur J Microbiol. 2015;8(4):e17157. doi:10.5812/jjm.8(4)2015.17157.

21. Heile JM, Fong YL, Rosa D, Berger K, Saletti G, Campagnoli S et al. Evaluation of hepatitis $\mathrm{C}$ virus glycoprotein E2 for vaccine design: an endoplasmic reticulum-retained recombinant protein is superior to secreted recombinant protein and DNA-based vaccine candidates. J Virol. 2000;74(15):6885-92.

22. Kumar M Sh, Rao Kh V, Reddy VD. Analysis of Envelope 1 (E1) and Hyper Variable Region-1 (HVR-1) Encoding Sequences from Indian Isolates of Hepatitis C Virus. The IUP Journal of Genetics \& Evolution. 2010;3(3):7-23.

23. Martinez-Donato G, Acosta-Rivero N, Morales-Grillo J, Musacchio A, Vina A, Alvarez $\mathrm{C}$ et al. Expression and processing of hepatitis $\mathrm{C}$ virus structural proteins in Pichia pastoris yeast. Biochem Biophys Res Commun. 2006;342(2):625-31. doi:10.1016/j.bbrc.2006.01.157. 